\title{
Evaluation of cationic polyamidoamine dendrimers' dermal toxicity in the rat skin model
}

This article was published in the following Dove Press journal:

Drug Design, Development and Therapy

5 March 2015

Number of times this article has been viewed

\author{
Katarzyna Winnicka' \\ Magdalena Wroblewska' \\ Katarzyna Sosnowska' \\ Halina Car ${ }^{2}$ \\ Irena Kasacka ${ }^{3}$
}

'Department of Pharmaceutical Technology, Faculty of Pharmacy, Medical University of Białystok, Białystok, Poland; ${ }^{2}$ Department of Experimental Pharmacology, Faculty of Health Sciences, Medical University of Białystok, Białystok, Poland; ${ }^{3}$ Department of Histology and Cytophysiology, Faculty of Pharmacy, Medical University of Białystok, Białystok, Poland
Correspondence: Katarzyna Winnicka Department of Pharmaceutical Technology, Faculty of Pharmacy, Medical University of Białystok, Kilinskiego I, 15-089 Białystok, Poland

Tel +48 8574856 I5

$\mathrm{Fax}+488574856 \quad 16$

Email kwin@umb.edu.pl

\begin{abstract}
Polyamidoamine (PAMAM) dendrimers are multi-branched, three-dimensional polymers with unique architecture, which makes these molecules attractive for medical and pharmaceutical applications. Using PAMAM as drug carriers for topical delivery might be beneficial as they only produce a transient effect without skin irritation. To evaluate the dermal toxicity of cationic PAMAM dendrimers generation 2 and generation 3, skin irritation studies were performed in vivo in the rat skin model. After 10 days topical application of various concentrations of PAMAM-NH $2(0.3 \mathrm{mg} / \mathrm{mL}, 3 \mathrm{mg} / \mathrm{mL}, 6 \mathrm{mg} / \mathrm{mL}, 30 \mathrm{mg} / \mathrm{mL}, 300 \mathrm{mg} / \mathrm{mL})$, skin irritation was evaluated by visual, histopathological, and immunohistochemical examination. Microscopic assessment after hematoxylin-eosin staining revealed significant morphological changes of epidermal cells after application of PAMAM- $\mathrm{NH}_{2}$ at a concentration of $\geq 6 \mathrm{mg} / \mathrm{mL}$. Morphological alterations of epidermal cells included cytoplasmic vacuolization of keratinocytes in the basal and spinous layers. Cytomorphological changes in keratinocytes, overall picture of the epidermis, and histopathological changes in the dermis were dose dependent. Detected alterations concerned hyperplasia of connective tissue fibers and leukocyte infiltration. Visible granulocyte infiltration in the upper dermis and sockets formed by necrotic, cornified cells in the hyperplastic foci of epithelium were also noted. Immunohistochemical analyses revealed that increased nuclear immunoreactivity to PCNA correlated with the concentration of PAMAM- $\mathrm{NH}_{2}$, but no significant differences in the cell proliferation activity in skin treated with PAMAM- $\mathrm{NH}_{2}$ generation 2 or generation 3 were observed. Significantly higher expression of PCNA extended throughout the skin layers might suggest abnormal cell proliferation, which, as a consequence, might even lead to neoplastic changes.
\end{abstract}

Keywords: cationic PAMAM dendrimers polymers, topical delivery, nanomaterials, in vivo toxicity, skin irritation test

\section{Introduction}

Dendrimers are well-defined, highly branched macromolecules with precisely controlled chemical structure and low polydispersity. They provide a number of opportunities for design of novel drug carriers, gene delivery systems, and imaging agents. ${ }^{1-3}$ Dendrimers have been found to be suitable carriers for a variety of drugs including anticancer, antiviral, antifungal or antibacterial, with capacity to improve their bioavailability. ${ }^{4-8}$ Among existing dendrimers, polyamidoamine (PAMAM) are the most intensively investigated. They consist of ethylenediamine nucleus and branches based on methyl acrylate and ethylenediamine. Half generations of PAMAM possess carboxyl surface groups, while complete full generations have amine or hydroxyl groups. The surface groups are responsible for their high solubility and reactivity, and internal cavities can be used in encapsulation of small molecules. PAMAM dendrimers have demonstrated 
potential use as vehicles in several routes of administration, including oral, ocular, parenteral, and transdermal., ${ }^{1,9,10}$

It was shown that PAMAM dendrimers enhanced transdermal delivery of many drugs, including indomethacin, ${ }^{11}$ ketoprofen, diflunisal, ${ }^{12} 8$-methoxypsoralen, ${ }^{13,14}$ and 5-fluorouracil. ${ }^{15}$ The skin penetration of cationic dendrimers increased with the increase in treatment time and was inversely related to the dendrimer molecular weight. ${ }^{16}$ Interestingly, the improved penetration caused by neutral or anionic dendrimers was significantly lower. The higher skin penetration of cationic dendrimers is probably due to their binding to the negatively charged skin, interacting with the intercellular lipids, ${ }^{15,17}$ changing the architecture of the lipid bilayer ${ }^{18}$ or even inducing holes formation in the cell membranes. ${ }^{19}$ Membrane disruption by inducing formation of nanoholes or causing membrane erosion as a consequence might cause leakage of cytosolic enzymes and cell lysis. ${ }^{19-21}$ The possible clinical use of dendrimers must be preceded by extensive in vivo toxicity studies. Before Vivage ${ }^{\circledR}$ (SPL7013) - the first product based on dendrimers (containing modified polylysine dendrimers) was introduced clinically, it was evaluated in various animal models: mice, guinea pigs, and macaques. ${ }^{22}$

Using dendrimers as drug carriers for topical delivery might be beneficial as they only produce a transient effect without skin irritation. Since, to our knowledge, there are no studies devoted to evaluation of cationic dendrimers toxicity after topical application, the goal of this work was to assess the dermal toxicity of PAMAM- $\mathrm{NH}_{2}$ dendrimers in vivo in the rat skin model. As the lower generations of cationic dendrimers showed greater penetration enhancement than the higher ones, ${ }^{15,17,23}$ PAMAM-NH 2 generation 2 (G2) and generation 3 (G3) (Figure 1) were applied in this study. Skin irritation was assessed after 10 days topical application of various concentrations of PAMAM $(0.3 \mathrm{mg} / \mathrm{mL}, 3 \mathrm{mg} / \mathrm{mL}$, $6 \mathrm{mg} / \mathrm{mL}, 30 \mathrm{mg} / \mathrm{mL}, 300 \mathrm{mg} / \mathrm{mL}$ ) by visual, histopathological, and immunohistochemical examination. Dissected skin samples were stained by hematoxylin-eosin (H and E) method and viewed using a light microscope for any pathological changes. Since PCNA immunostaining is widely used for detecting proliferating cells in tissue sections, especially of neoplastic lesions, the distribution of PCNA immunoreactivity (PCNA-IR) cells in the skin of rats treated with various concentrations of PAMAM-NH ${ }_{2}$ dendrimers was determined. The morphometric features of PCNA-IR nuclei, intensity of immunohistochemical reaction, and thickness of the epidermis were also evaluated.

\section{Materials and methods Reagents}

PAMAM dendrimers G2 and G3 with amine surface groups were provided by Sigma-Aldrich Co. (St Louis, MO, USA), as were most other chemicals used. To prepare water solutions of PAMAM, methanol was evaporated from purchased solutions by using Centrivap Concentrator FreeZone6 (Labconco, Kansas City, MO, USA). Reagents for routine histological $\mathrm{H}$ and $\mathrm{E}$ staining, a specific monoclonal mouse anti-PCNA clone PC10 M 0879, target retrieval solution S 1699, antibody diluent S 0809, and wash buffer S 3006 were obtained from Dako Denmark A/S (Glostrup, Denmark).

\section{Animals}

Male Wistar rats, weighing 150-200 g were fed a standard diet and housed in plastic cages $(50 / 40 / 20 \mathrm{~cm})$, one animal per cage, in an air-conditioned and temperature-controlled $\left(21^{\circ} \mathrm{C} \pm 2^{\circ} \mathrm{C}\right)$ room with a 12 hours light/dark cycle. Food and water were freely available. All experiments were carried out in a quiet, diffusely lit room. ${ }^{24}$ The in vivo experimental protocol was approved by the Ethics Commission of the Medical University of Białystok, Poland. On the day prior to the experiment, the animals were anesthetized with pentobarbital $40 \mathrm{mg} / \mathrm{kg}$ body weight (bw) and the hair on the dorsal side of the rats (area $4 \times 2 \mathrm{~cm}$ ) was carefully removed with an electric hair clipper in the direction of tail to head without damaging the skin.

\section{Study design}

The rats were divided into XII groups $(n=6)$. Group I served as control, without any treatment; group II was administrated $0.8 \%$ aqueous solution of formalin as a standard irritant; groups III-XII were treated with $100 \mu \mathrm{L}$ of water solutions of various concentrations of PAMAM-NH dendrimers $\mathrm{G} 2$ or $\mathrm{G} 3(0.3 \mathrm{mg} / \mathrm{mL}, 3 \mathrm{mg} / \mathrm{mL}, 6 \mathrm{mg} / \mathrm{mL}$, $30 \mathrm{mg} / \mathrm{mL}, 300 \mathrm{mg} / \mathrm{mL}$ ), which corresponded to $0.17,1.67$, $3.33,16.67$, and $166.67 \mathrm{mg} / \mathrm{kg}$ bw. Tested solutions were applied to the exposed skin and spread over the entire area, once a day during a 10-day period. Finally, the application sites were evaluated visually always by the same investigator and graded according to a standard visual scoring scale: 0 - no erythema, 1 - slight erythema (barely perceptiblelight pink), 2 - moderate erythema (dark pink), 3 - moderate to severe erythema (light red), 4 - severe erythema (extreme redness). ${ }^{25}$ Then rats were sacrificed by decapitation under pentobarbital anesthesia $(80 \mathrm{mg} / \mathrm{kg} \mathrm{bw})$ and dorsal 

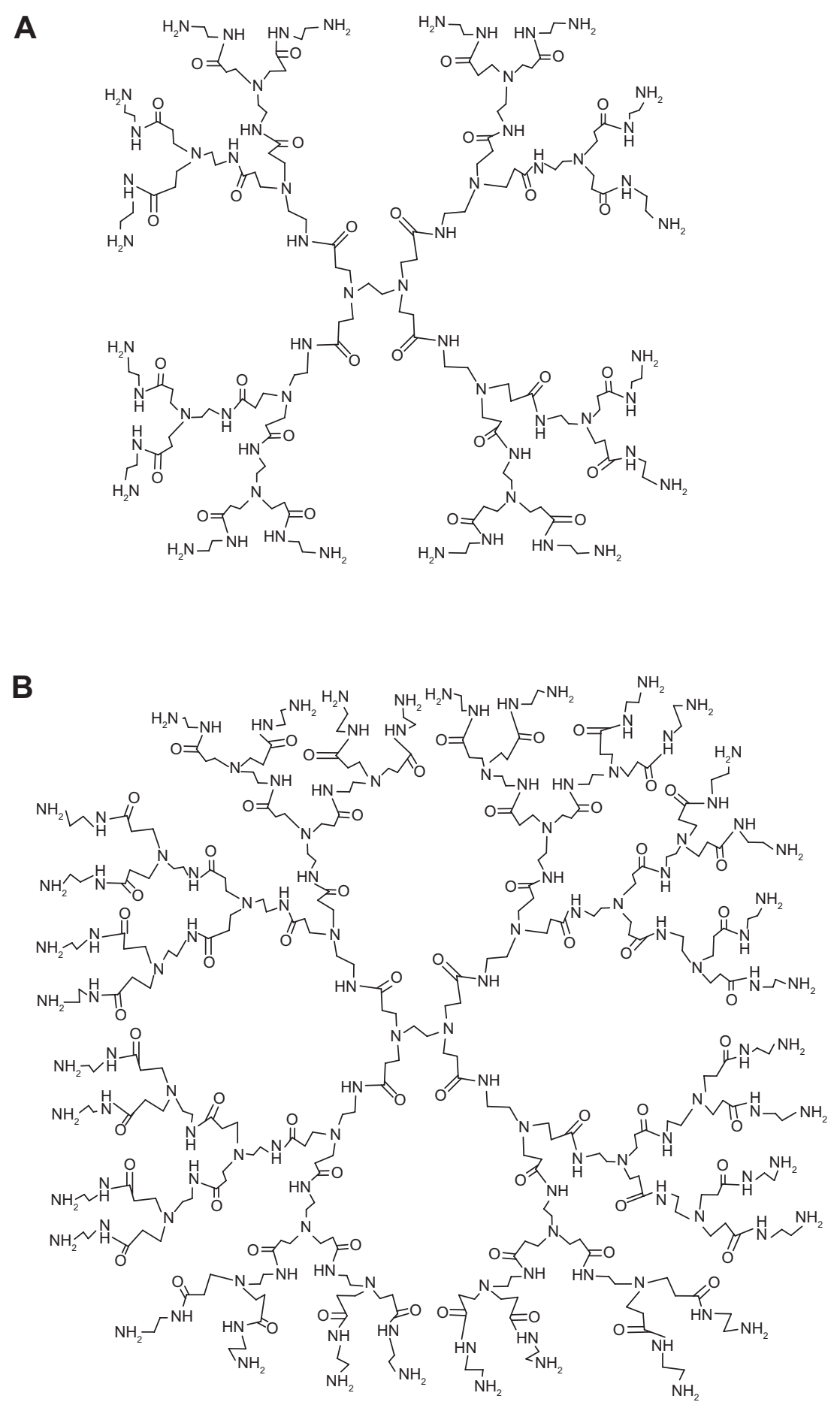

Figure I Chemical structure of polyamidoamine- $\mathrm{NH}_{2}$ dendrimer generation $2(\mathbf{A})$ and generation 3 (B).

skin samples from treated and untreated (control) areas were taken for histological and immunohistochemical studies. The Kruskal-Wallis analysis was used to check whether control groups were equal among themselves and to test any differences among all groups (control and experimental).

\section{Histopathology}

\section{Light microscopy}

The skin samples were fixed in $4 \%$ buffered formaldehyde and routinely embedded in paraffin. Sections, $4 \mu \mathrm{m}$ thick, were cut using rotary microtome, Leica 2025 (Leica Microsystems, Wetzlar, Germany) and stained by $\mathrm{H}$ and $\mathrm{E}$ 
and by Azan method for general histological examination. Tissue sections were viewed by one pathologist using a light microscope, Olympus BX41 (Olympus Corporation, Tokyo, Japan) interfaced with an image analysis system. The images were captured using a DP12 camera (Olympus Corporation).

\section{Immunohistochemical procedures}

\section{Evaluation of cell proliferation by PCNA staining}

The paraffin blocks were cut into $4 \mu \mathrm{m}$ sections, mounted onto Superfrost Plus slides (Menzel Gläser, Braunschweig, Germany) and dried overnight at $37^{\circ} \mathrm{C}$ followed by 1 hour at $60^{\circ} \mathrm{C}$. An immunohistochemical reactions to find PCNA was performed on paraffin skin sections of the animals. In these studies a specific monoclonal mouse anti-PCNA clone PC10 was used (M 0879; Dako Denmark A/S). The EnVision method according to Herman and Elfont was applied. ${ }^{26}$ Control reactions were simultaneously performed. In the negative control, the specific antibody was omitted in the staining procedure and control reaction performed gave negative results. Positive control was done for specific tissue recommended by producer - for PCNA it is human colon.

Immunostaining was performed by the following protocol: paraffin-embedded sections were deparaffinized and hydrated in pure alcohol. After washing with distilled water, sections were pretreated with antigen retrieval in a pressure chamber heating for 1 minute at 21 psi ( 1 psi equates to $6.895 \mathrm{kPa}$, the conversion factor provided by the United Kingdom National Physical Laboratory) at $125^{\circ} \mathrm{C}$ using target retrieval solution S 1699 . After being cooled at room temperature, sections were incubated with peroxidase blocking reagent for 10 minutes to block endogenous peroxidase activity. Primary antibody was diluted 1:4,000 using the antibody diluent $\mathrm{S} 0809$. The sections were incubated overnight at $4^{\circ} \mathrm{C}$ in a humidified chamber with the diluted antibody, followed by incubation with labeled polymer per 1 hour (EnVision System HRP Mouse Kit K4007; Dako Denmark A/S). Appropriate washing with wash buffer S 3006 was performed in-between each step. Then sections were incubated in liquid 3,3'-diaminobenzidine $(+)$ chromogen, controlled under microscope. Finally the sections were counterstained in Vector QS hematoxylin mounted and evaluated under light microscope. The nature of staining and the distribution of PCNA-IR were determined. A cell was scored as positive when there was distinct brown granular staining of the nucleus regardless of its intensity.

\section{Quantitative analysis of PCNA staining and imaging}

The analysis of the preparations and their photographic documentation were performed using an Olympus BX41 light microscope (Olympus Corporation) equipped with Olympus DP12-2 camera (Olympus Corporation). Images from five randomly selected microscopic fields (each field $0.785 \mathrm{~mm}^{2}$ ), at a magnification of $200 \times$ were morphometrically evaluated by using image analysis software (NIS-Elements Advanced Research Nikon software, Nikon Instruments, Melville, NY, USA).

The number of PCNA-IR cells was counted in each analyzed image and presented as median per visual field $\left(0.785 \mathrm{~mm}^{2}\right)$. Morphological characteristics of PCNA-IR nuclei, (diameter, area), intensity of immunohistochemical reaction, and thickness of the epidermis were also evaluated. Intensity of immunohistochemical reaction was measured by using 0 to 256 gray scale level, where completely black pixel had a value of 0 , and completely white or bright one possessed a value of 256. The gray scale intensity and PCNA expression have inverse relation.

\section{Statistical analysis}

Quantitative variables were expressed as the median with $25 \%-75 \%$ quartile range. A statistical analysis was performed using nonparametric technique, the Kruskal-Wallis with Dunn's post hoc test with the Statistica 10.0 software (StatSoft, Kraków, Poland). Differences between groups were considered to be significant at $P<0.05$.

\section{Results and discussion}

Despite PAMAM dendrimers being promising drug delivery systems and their potential commercial applications having received considerable attention, the majority of studies performed to date focused on dendrimer toxicity evaluated in vitro. It was shown that PAMAM dendrimers demonstrated generation, surface charge and concentration dependent cytotoxicity. ${ }^{27-29}$ Assays in vitro provide cell type specific information, but do not accurately reflect dendrimers' in vivo behavior. Limited studies have been performed to investigate dendrimer toxicity in vivo - there are only few studies concerning toxicity of PAMAM dendrimers after oral or parenteral administration. ${ }^{21}$ It was found that lower generations of PAMAM administered parenterally did not cause behavioral changes or weight loss, but for higher generations, incidents of mice death were noted. Roberts et al studied toxicity of PAMAM G3, G5, and G7 after 
intraperitoneal administration in Swiss-Webster mice at doses of $2.6,10.0$, and $45.0 \mathrm{mg} / \mathrm{kg}$ bw. These studies suggested that cationic dendrimers $(G<7)$ even at high doses did not cause adverse effects. ${ }^{30}$ However, Heiden et al found that cationic PAMAM dendrimers G4 were toxic to zebrafish embryos, and the toxicity was dose and exposure duration dependent. Exposure to $\geq 20 \mu \mathrm{M}(\sim 0.283 \mathrm{mg} / \mathrm{mL}) \mathrm{G} 4$ dendrimer caused $100 \%$ mortality by 24 hours post fertilization. Otherwise, in the same study anionic PAMAM dendrimers G3.5 were not toxic and reveled no signs of embryo development impairment. ${ }^{31}$ Malik et al found that $95 \mathrm{mg} / \mathrm{kg}$ bw daily doses of anionic PAMAM dendrimers (G3.5, carboxylic acid termini) administered intraperitoneally led to no mortalities and no weight change in B16F10 tumor bearing mice. ${ }^{32}$ Chauhan et al examined toxicity profile of PAMAM-NH $\mathrm{N}_{2}$ and PAMAM-OH dendrimers G4 (4.75-19.0 mg/kg bw) via the intraperitoneal route for 15 days in Swiss albino mice and observed no significant effect on feed intake, body and organ weights, lipid and protein metabolism, hematological parameters, and histopathology. ${ }^{33}$ Generally, it was shown that the rank order of PAMAM toxicity is hydroxyl-terminated < carboxylterminated $<$ amine-terminated dendrimers. ${ }^{1,29,34}$

Although several reports have studied PAMAM as potential skin penetration enhancers and nanocarriers for transdermal delivery, ${ }^{11-16,35}$ the toxicity of PAMAM after topical administration is largely unknown. Therefore, in this study to evaluate dermal toxicity of PAMAM-NH $\mathrm{N}_{2}$ and G3 after topical administration, skin irritation test in the rat skin model was performed. Rodents' skin model (mice, rats, guinea pigs) is commonly used for irritation and permeability studies in vivo. ${ }^{36-38}$ Among rodents, rat skin is considered the most structurally similar to human tissue. However, rat skin is more permeable and more sensitive than human skin because it is significantly thinner - it possesses lower thickness of stratum corneum and epidermis. ${ }^{38}$

The skin irritation test was carried out after 10 days topical application of PAMAM by both visual observation (Figure 2A-G) and histopathological examination (Figure 3A-G). It was shown that PAMAM-NH 2 G2 and G3 were well tolerated at concentrations up to $3 \mathrm{mg} / \mathrm{mL}$. After 10 days administration, there were no signs of erythema (Figure 2C). Slight erythema in case of PAMAM-NH $\mathrm{N}_{2}$ at a concentration of $6 \mathrm{mg} / \mathrm{mL}$ was noted (Figure 2D). Moderate erythema (Figure 2E) and severe erythema (Figure 2F) of skin was observed in rats treated with significantly higher $(30 \mathrm{mg} /$ $\mathrm{mL}$ and $300 \mathrm{mg} / \mathrm{mL}$, respectively) concentrations of PAMAM$\mathrm{NH}_{2} \mathrm{G} 2$ and $300 \mathrm{mg} / \mathrm{mL}$ PAMAM-NH 2 G3 (Figure 2G).

Microscopic evaluation of the skin sections stained with $\mathrm{H}$ and $\mathrm{E}$ revealed significant morphological changes of epidermal cells after 10 days application of PAMAM- $\mathrm{NH}_{2}$ $\mathrm{G} 2$ at a concentration of $6 \mathrm{mg} / \mathrm{mL}$. Morphological changes of epidermal cells included cytoplasmic vacuolization of keratinocytes in the basal and spinous layers (Figure 3D). It was also demonstrated that cytomorphological changes in keratinocytes, overall picture of the epidermis and histopathological changes in the dermis were dose dependent. Moreover, noticeable histopathological changes in the dermis after application of PAMAM at the concentration of $30 \mathrm{mg} / \mathrm{mL}$ (Figure 3E) and $300 \mathrm{mg} / \mathrm{mL}$ (Figure 3F and G) were observed. Detected alterations concerned hyperplasia

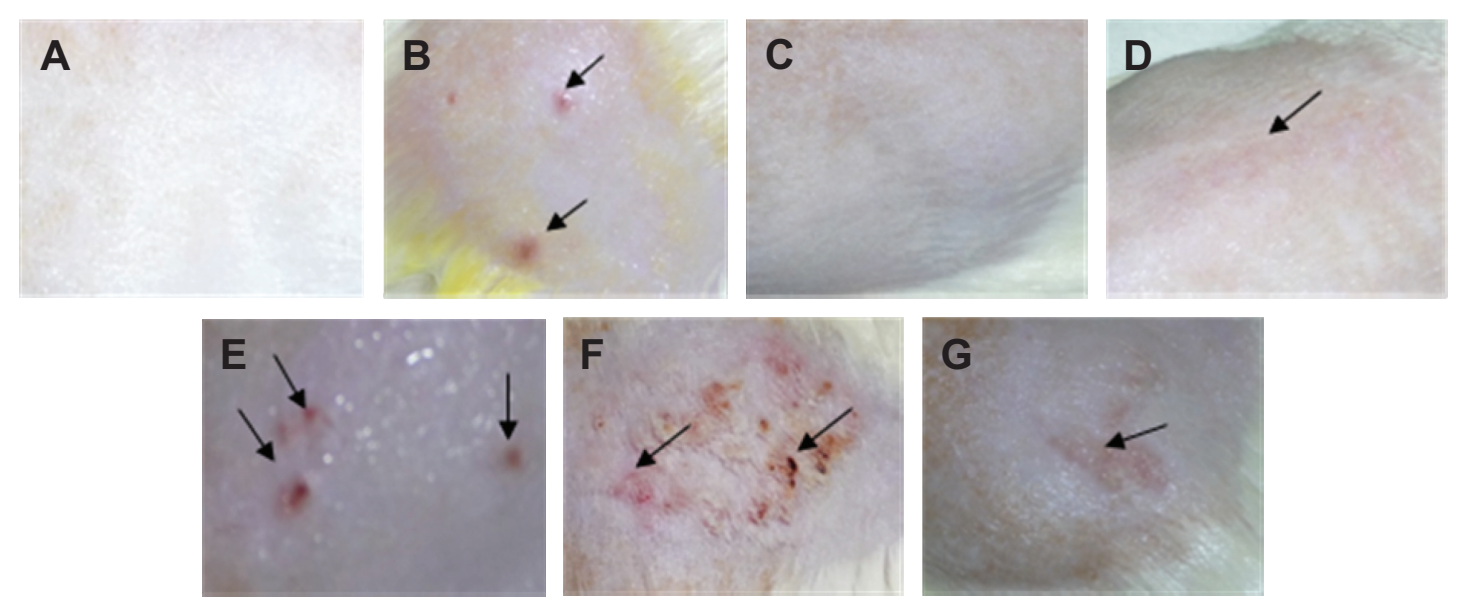

Figure 2 Representative images of the skin irritation test.

Notes: (A) Control rat skin; (B) skin treated with $100 \mu \mathrm{L}$ of $0.8 \%$ formalin, various concentrations of PAMAM-NH 2 generation 2: (C) $3 \mathrm{mg} / \mathrm{mL}$, (D) $6 \mathrm{mg} / \mathrm{mL}$, (E) $30 \mathrm{mg} / \mathrm{mL}$, (F) $300 \mathrm{mg} / \mathrm{mL}$ PAMAM- $\mathrm{NH}_{2}$ generation 2 and (G) $300 \mathrm{mg} / \mathrm{mL}$ PAMAM-NH ${ }_{2}$ generation 3. Arrows indicate the location of erythema.

Abbreviation: PAMAM, polyamidoamine. 

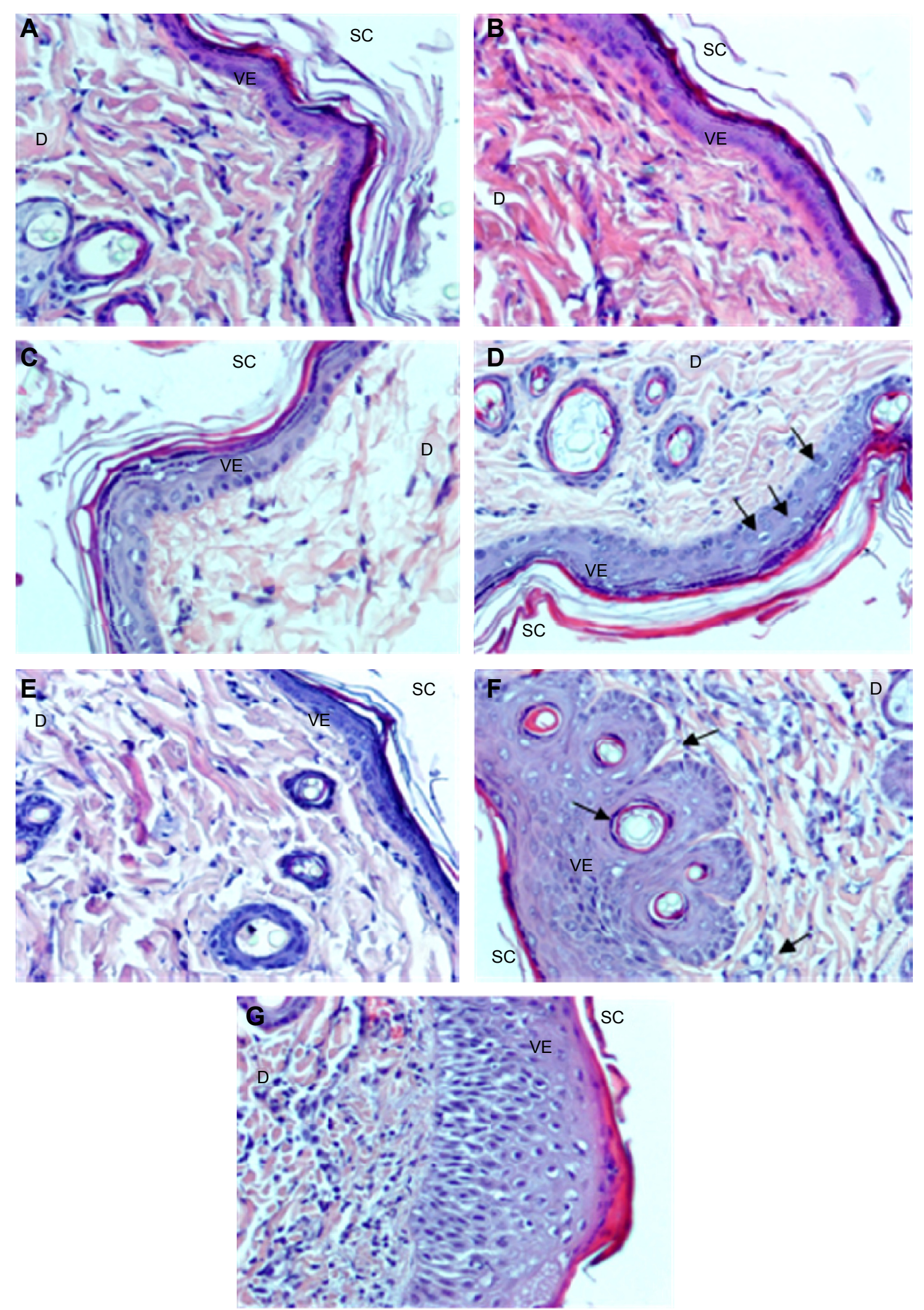

Figure 3 Representative images of the skin sections.

Notes: (A) Control rats, skin treated with $100 \mu \mathrm{L}$ of $0.8 \%$ formalin (B) and various concentrations of PAMAM-NH 2 generation $2:($ C) $3 \mathrm{mg} / \mathrm{mL}$, (D) $6 \mathrm{mg} / \mathrm{mL}$, (E) $30 \mathrm{mg} / \mathrm{mL}$; (F and G) $300 \mathrm{mg} / \mathrm{mL}$. Reported vacuolization of keratinocytes in the basal and spinous layers (arrows) (D), inflammatory infiltrations of leukocytes and connective tissue fibers hyperplasia (dermis) (F and $\mathbf{G}$ ) and apoptotic keratinocytes (epidermis) and granulocyte infiltration in the upper dermis (F) (arrows). $\mathrm{H}$ and $\mathrm{E}$ staining, magnification $\times 200$. Abbreviations: PAMAM, polyamidoamine; SC, stratum corneum; VE, viable epidermis; D, dermis; $\mathrm{H}$ and $\mathrm{E}$, hematoxylin-eosin. 
of connective tissue fibers and leukocyte infiltration. Visible granulocyte infiltration in the upper dermis and sockets formed by necrotic, cornified cells in the hyperplastic foci of epithelium was also noted (Figure 3F).

The influence of PAMAM on the cell proliferation was evaluated by PCNA staining. PCNA is a $36 \mathrm{kDa}$ molecular weight protein. It is an auxiliary protein for DNA polymerase delta that is involved in DNA replication as well as DNA repair mechanism. Its synthesis and expression is related to the proliferating state of the cell and its level of expression reflects cell proliferating activity. ${ }^{39,40}$ Immunohistochemical staining for PCNA allows the identification of cells in the different phases of the cycle. Expression of PCNA increases in late $\mathrm{G}_{1}$, is maximally expressed in the $\mathrm{S}$ phase, and decreases in $\mathrm{G}_{2}-\mathrm{M}$ phase of the cell cycle. ${ }^{40,41}$ This makes it a useful marker for proliferated cells. It is present to some degree in normal cells, while in malignancies the increase in PCNA is probably related to uncontrolled DNA synthesis and disturbed cell cycle. ${ }^{41,42}$

Immunohistochemical analyses of skin treated with various concentrations of PAMAM-NH $\mathrm{N}_{2} \mathrm{G}$ and $\mathrm{G} 3(0.3 \mathrm{mg} / \mathrm{mL}$, $3 \mathrm{mg} / \mathrm{mL}, 6 \mathrm{mg} / \mathrm{mL}, 30 \mathrm{mg} / \mathrm{mL}, 300 \mathrm{mg} / \mathrm{mL}$ ) (Figure 4A-H) revealed that increased nuclear immunoreactivity to PCNA was concentration dependent, but no significant differences in the cell proliferation activity in skin treated with PAMAM G2 or G3 was observed. Increased expression of PCNA was found in the majority of basal cell layers. However, after application of higher concentrations of PAMAM, the increased number of PCNA-IR cells was observed not only in basal layer but also in the superficial layers of epidermis (Figure 4). In the control epidermis, only few PCNA-IR nuclei were found in the cells lying in the basal layer (Figure 4A). In epidermal keratinocytes of rats treated with $0.3 \mathrm{mg} / \mathrm{mL}$ PAMAM- $\mathrm{NH}_{2}$ G2 and G3, PCNA expression was similar to the control. The expression was limited only to the cells in the basal layer, while other cell layers of the epidermis showed negative staining (Figure 4C). It was noticed that the number of PCNA-IR cells in the epidermis of skin treated with $3 \mathrm{mg} / \mathrm{mL}$ PAMAM-NH${ }_{2}$ was higher (Figure 4D). Location of keratinocytes with PCNA-IR nuclei after application of PAMAM-NH $\mathrm{N}_{2} 6 \mathrm{mg} / \mathrm{mL}$ was significantly different from control skin tissue. As it is shown in Figure 4E, PCNA was observed in almost all the cells of the lowest layer. After administration of PAMAM-NH $\mathrm{N}_{2}$ at a concentration of $30 \mathrm{mg} / \mathrm{mL}$, a substantial increase in epidermal keratinocytes hyperplasia was noted and PCNA-IR cells were not detected only in the stratum corneum (Figure 4F). In skin of rats treated with $300 \mathrm{mg} / \mathrm{mL}$ PAMAM-NH $\mathrm{N}_{2}$ G2 or G3, PCNA-IR cells significantly extended throughout the epidermis (Figure 4G and $\mathrm{H}$ ). The amount of cells demonstrated positive nuclear staining for PCNA and the intensity of reaction is presented in Figure 5. As it is demonstrated, the rise in the amount of PCNA-IR cells and the visible increase in the intensity of immunohistochemical reaction was observed in rat skin samples after application of PAMAM- $\mathrm{NH}_{2}$ dendrimers at a concentration of $3 \mathrm{mg} / \mathrm{mL}$. Substantial growth of the intensity of the immunohistochemical reaction in case of higher concentrations $\left(30 \mathrm{mg} / \mathrm{mL}\right.$ and $300 \mathrm{mg} / \mathrm{mL}$ ) of PAMAM- $\mathrm{NH}_{2}$ was detected. PCNA related DNA repair in response to possible mutagens is critical to maintain the cellular genomic integrity, therefore the increase in the amount of PCNA-IR cells after application of PAMAM- $\mathrm{NH}_{2}$ is probably a consequence of enhanced DNA repair processes as a reaction to DNA damage.

As nuclear size is a very important parameter, which changes in dysplasia and reflects the intensified DNA synthesis, and the abnormalities of nuclear features have been reported in various types of carcinoma, ${ }^{43,44}$ morphological characteristics of PCNA-IR nuclei were investigated. Obtained results revealed that there was no significant differences in diameter and area of nuclei after administration of PAMAM- $\mathrm{NH}_{2}$ at concentrations up to $3 \mathrm{mg} / \mathrm{mL}$ (Figure 6). The increase in the area and diameter of the nuclei was concentration dependent. Visible growth of the nuclei area and nuclei diameter was noted at a concentration of $\geq 6 \mathrm{mg} / \mathrm{mL}$ of PAMAM-NH ${ }_{2}$.

The influence of various concentrations of PAMAM$\mathrm{NH}_{2}$ on the epidermal thickness was also investigated (Figure 7). Epidermal thickness was defined as the distance between the basement membrane and the apical surface of the uppermost nucleated keratinocytes (the border between the stratum granulosum and stratum corneum). ${ }^{45}$ The epidermis is a continuously renewing tissue in which homeostasis is maintained by a regulated balance between cell proliferation, cell differentiation and programmed cell death. In the normal epidermis, proliferating cells are confined to the basal layer, whereas apoptosis appears at the border of the stratum granulosum and stratum corneum. ${ }^{45}$ As assessed by the image analyzer, the epidermal thickness of control skin samples was $21.02 \mu \mathrm{m}$ (expressed as median). After application of PAMAM- $\mathrm{NH}_{2}$ at a concentration of $6 \mathrm{mg} / \mathrm{mL}$, only a slight rise in the epidermal thickness was observed $(25.49 \mu \mathrm{m})$. The increase of epidermal thickness was concentration dependent and in the group of rats 

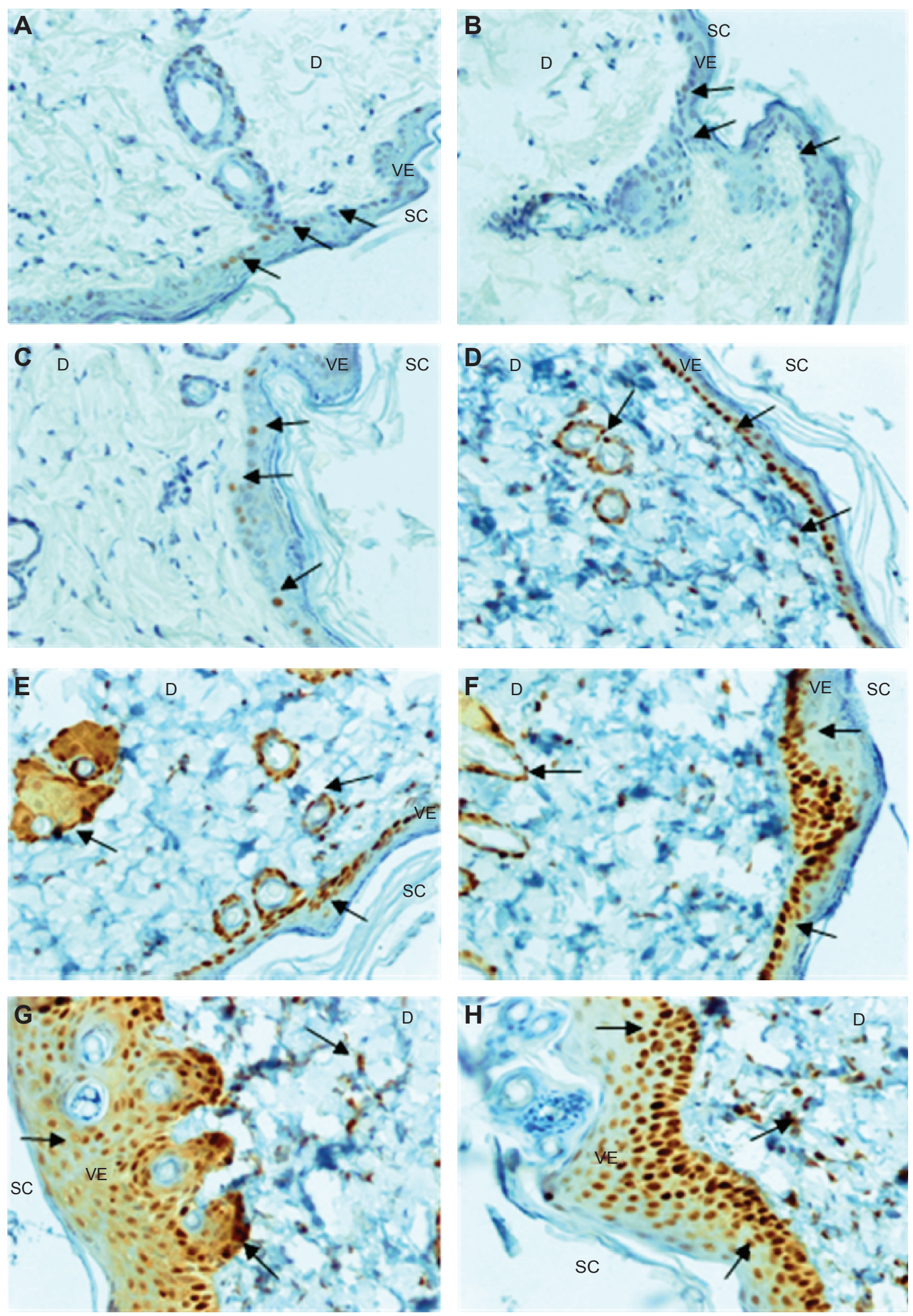

Figure 4 Immunohistochemical reactivity for PCNA.

Notes: (A) Control rat, skin treated with $100 \mu \mathrm{L}$ of $0.8 \%$ formalin (B), and various concentrations of PAMAM- $\mathrm{NH}_{2}$ generation 2: (C) $0.3 \mathrm{mg} / \mathrm{mL}$; (D) $3 \mathrm{mg} / \mathrm{mL} ;($ E) $6 \mathrm{mg} / \mathrm{mL}$; (F) $30 \mathrm{mg} / \mathrm{mL}$; (G) $300 \mathrm{mg} / \mathrm{mL}$, and PAMAM-NH $\mathrm{N}_{2}$ generation $3300 \mathrm{mg} / \mathrm{mL}$ (H). Arrows demarcate areas of PCNA immunoreactive cells; magnification $\times 200$.

Abbreviations: SC, stratum corneum; VE, viable epidermis; D, dermis; PAMAM, polyamidoamine. 
A

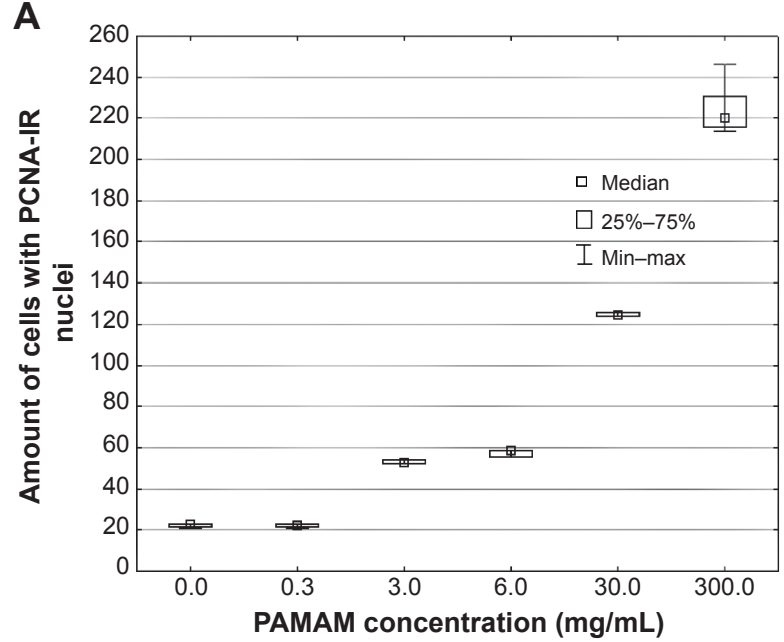

B

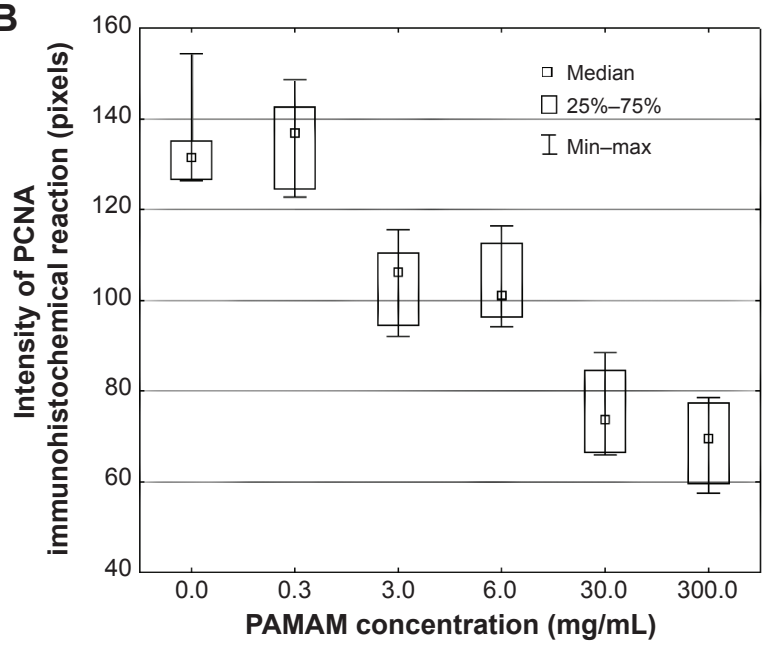

Figure 5 Quantitative image analysis of PCNA-staining.

Notes: (A) Amount of cells with PCNA-IR nuclei, (B) intensity of immunohistochemical reaction in the rat skin sections treated with I00 $\mu \mathrm{L}$ of various concentrations of PAMAM-NH ${ }_{2}$ generation 2: $0.3 \mathrm{mg} / \mathrm{mL}, 3 \mathrm{mg} / \mathrm{mL}, 6 \mathrm{mg} / \mathrm{mL}, 30 \mathrm{mg} / \mathrm{mL}, 300 \mathrm{mg} / \mathrm{mL}(\mathrm{n}=6)$.

Abbreviations: PAMAM, polyamidoamine; PCNA-IR, PCNA immunoreactivity; Min, minimum; Max, maximum.

treated with $300 \mathrm{mg} / \mathrm{mL}$ PAMAM- $\mathrm{NH}_{2}$ epidermal thickness $(94.07 \mu \mathrm{m})$ was over fourfold higher than in the control group (Figure 7).

Significantly higher expression of PCNA extended throughout the skin layers, epidermal hyperplasia and increasing aberrations of nuclear features after administration of higher concentrations of PAMAM- $\mathrm{NH}_{2}$ suggest disorganized cell proliferation. Abnormal cell proliferation, which results from deregulation of the cell cycle, might even lead to neoplastic changes. In conclusion, microscopic assessment after $\mathrm{H}$ and $\mathrm{E}$ staining and immunohistochemical analyses revealed that PAMAM dendrimers with positively charged surface groups are prone to exhibit significant dermal toxicity and in potent topical applications only lower concentrations of PAMAM should be considered. Obtained data can be useful to design dendrimer-based nanocarriers for drug delivery to skin.

\section{Acknowledgment}

This research was supported by Medical University of Białystok grant (143-15780 F).
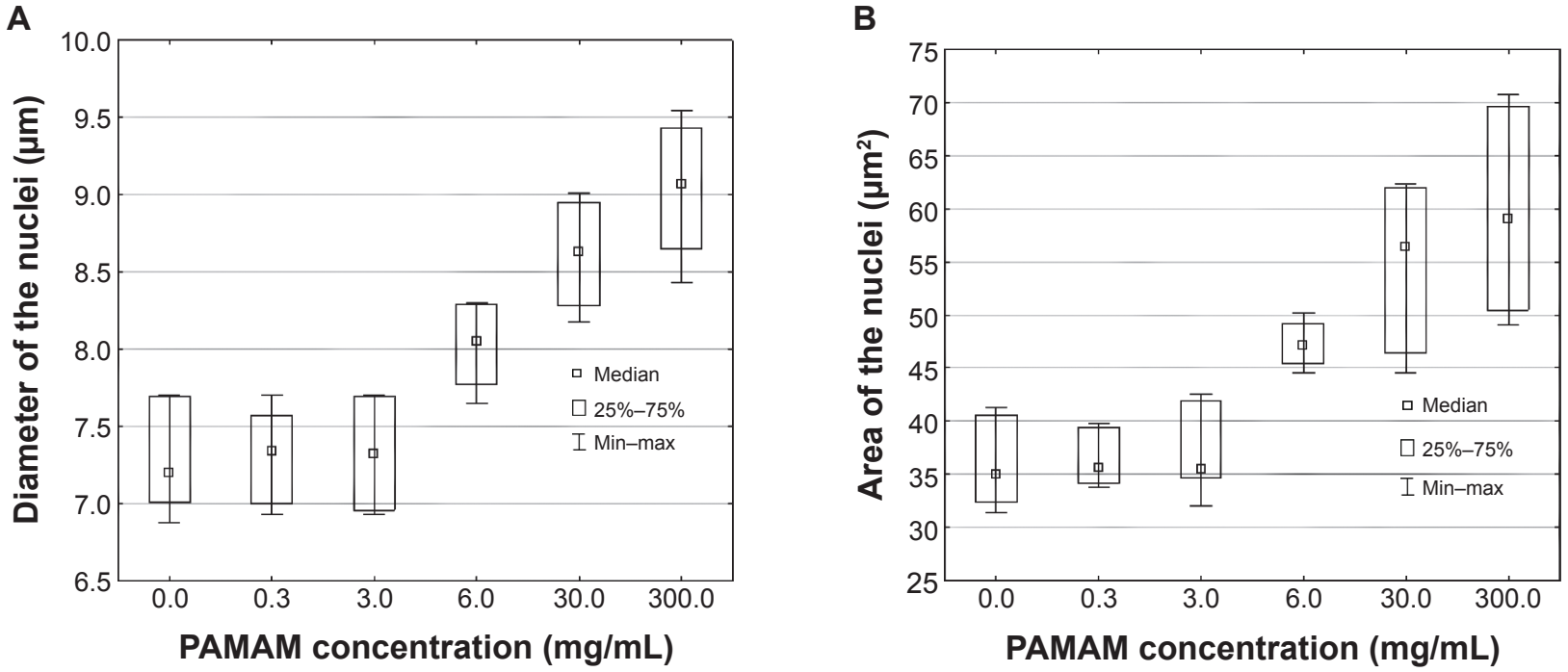

Figure 6 Effect of various concentrations of PAMAM- $\mathrm{NH}_{2}$ generation 2.

Notes: $0.3 \mathrm{mg} / \mathrm{mL}, 3 \mathrm{mg} / \mathrm{mL}, 6 \mathrm{mg} / \mathrm{mL}, 30 \mathrm{mg} / \mathrm{mL}$, and $300 \mathrm{mg} / \mathrm{mL}$ on: (A) diameter and (B) area of PCNA-IR nuclei $(\mathrm{n}=6)$.

Abbreviations: PAMAM, polyamidoamine; PCNA-IR, PCNA immunoreactivity; Min, minimum; Max, maximum. 


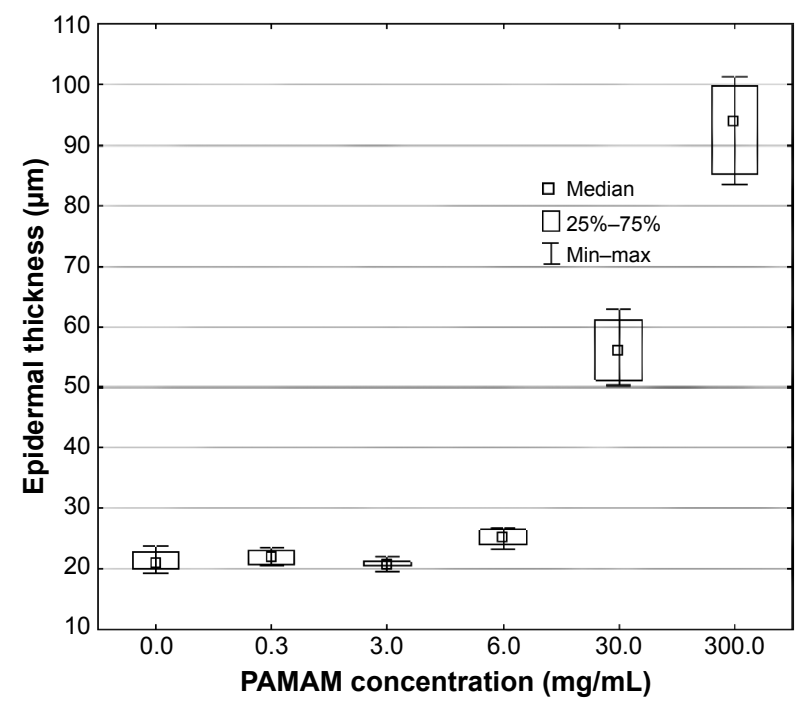

Figure 7 Effect of various concentrations of PAMAM-NH $\mathrm{H}_{2}$ generation 2. Notes: $0.3 \mathrm{mg} / \mathrm{mL}, 3 \mathrm{mg} / \mathrm{mL}, 6 \mathrm{mg} / \mathrm{mL}, 30 \mathrm{mg} / \mathrm{mL}$, and $300 \mathrm{mg} / \mathrm{mL}$ on epidermal thickness $(n=6)$.

Abbreviations: PAMAM, polyamidoamine; Min, minimum; Max, maximum.

\section{Disclosure}

The authors declare no conflicts of interest in this work.

\section{References}

1. Svenson S, Tomalia DA. Dendrimers in biomedical applications - reflections on the field. Adv Drug Deliv Rev. 2005;57(15): 2106-2129.

2. Nanjwade BK, Bechra HM, Derkar GK, Manvi FV, Nanjwade VK. Dendrimers: emerging polymers for drug-delivery systems. Eur $J$ Pharm Sci. 2009;38(3):185-196.

3. Kandekar UY, Chaudhari PD, Tambe VS, Vichare VS, Dhole SN. Dendrimers: novel drug nanocarriers. Int J Pharm Sci Res. 2011;2(5): 1086-1098.

4. Winnicka K, Bielawski K, Bielawska A. Synthesis and cytotoxic

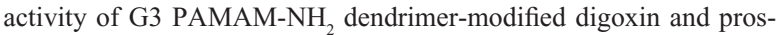
cillaridin A conjugates in breast cancer cells. Pharmacol Rep. 2010; 62(2):414-423.

5. Huh AJ, Kwon YJ. Nanoantibiotics: A new paradigm for treating infectious diseases using nanomaterials in the antibiotics resistant era. J Control Release. 2011;156(2):128-145.

6. Winnicka K, Sosnowska K, Wieczorek P, Sacha PT, Tryniszewska E. Poly(amidoamine) dendrimers increase antifungal activity of clotrimazole. Biol Pharm Bull. 2011;34(7):1129-1133.

7. Charles S, Vasanthan N, Kwon D, Sekosan G, Ghosh S. Surface modification of poly(amidoamine) (PAMAM) dendrimer as antimicrobial agents. Tetrahedron Lett. 2012;53(49):6670-6675.

8. Cheng Y, Qu H, Ma M, et al. Polyamidoamine (PAMAM) dendrimers as biocompatible carriers of quinolone antimicrobials: an in vitro study. Eur J Med Chem. 2007;42(7):1032-1038.

9. Cheng Y, Xu Z, Ma M, Xu T. Dendrimers as drug carriers: Applications in different routes of drug administration. J Pharm Sci. 2008; 97(1):123-143.

10. Filipowicz A, Wołowiec S. Bioconjugates of PAMAM dendrimers with trans-retinal, pyridoxal, and pyridoxal phosphate. Int J Nanomedicine. 2012;7:4819-4828.

11. Chauhan AS, Sridevi S, Chalasani KB, et al. Dendrimer-mediated transdermal delivery: enhanced bioavailability of indomethacin. J Control Release. 2003;90(3):335-343.
12. Cheng YY, Man N, Xu TW, et al. Transdermal delivery of nonsteroidal anti-inflammatory drugs mediated by polyamidoamine (PAMAM) dendrimers. J Pharm Sci. 2007;96(3):595-602.

13. Borowska K, Wołowiec S, Rubaj A, Głowniak K, Sieniawska E, Radej S. Effect of polyamidoamine dendrimer G3 and G4 on skin permeation of 8-methoxypsoralene - in vivo study. Int J Pharm. 2012;426(1-2): 281-283.

14. BorowskaK, Wołowiec S, GłowniakK, SieniawskaE, RadejS. Transdermal delivery of 8-methoxypsoralene mediated by polyamidoamine dndrimer G2.5 and G3.5 - in vitro and in vivo study. Int J Pharm. 2012;436(1-2): 764-770.

15. Venuganti VK, Perumal OP. Effect of poly(amidoamine) PAMAM dendrimers on the skin permeation of 5-fluorouracil. Int J Pharm. 2008; 361(1-2):230-238.

16. Venuganti VV, Sahdev P, Hildreth M, Guan X, Perumal O. Structureskin permeability relationship of dendrimers. Pharm Res. 2011; 28(9):2246-2260.

17. Venuganti VK, Perumal OP. Poly(amidoamine) dendrimers as skin penetration enhancers. Influence of charge, generation and concentration. J Pharm Sci. 2009;98(7):2345-2356.

18. Shcharbin D, Drapeza A, Loban V, Lisichenok A, Bryszewska M. The breakdown of bilayer lipid membranes by dendrimers. Cell Mol Biol Lett. 2006;11(2):242-248.

19. Mecke A, Uppuluri S, Sassanella TJ, et al. Direct observation of lipid bilayer disruption by poly(amidoamine) dendrimers. Chem Phys Lipids. 2004;132(1):3-14.

20. Leroueil PR, Berry SA, Duthie K, et al. Wide varieties of cationic nanoparticles induce defects in supported lipid bilayers. Nano Lett. 2008; $8(2): 420-424$

21. Shcharbin D, Janaszewska A, Klajnert-Maculewicz B, et al. How to study dendrimers and dendriplexes III. Biodistribution, pharmacokinetics and toxicity in vivo. J Control Release. 2014;181:40-52.

22. Patton DL, Cosgrove Sweeney YT, McCarthy TD, Hillier SL. Preclinical safety and efficacy assessments of dendrimer-based (SPL7013) microbicide gel formulations in a nonhuman primate model. Antimicrob Agents Chemother. 2006;50(5):1696-1700.

23. Yang Y, Sunoqrot S, Stowell Ch, et al. Effect of size, surface charge and hydrophobicity of poly(amidoamine) dendrimers on their skin penetration. Biomacromolecules. 2012;13(7):2154-2162.

24. Car H, Michaluk P. Effects of baclofen on acquisition and MMP-2, MMP-9 level. Pharmacol Rep. 2012;64(3):536-545.

25. Barakat NS. Evaluation of glucofurol-based gel as a new vehicle for topical application of naproxen. AAPS Pharm Sci Tech. 2010;11(3): 1138-1146.

26. Herman GE, Elfont EA. The taming of immunohistochemistry: the new era of quality control. Biotech Histochem. 1991;66(4):194-199.

27. Sadekar S, Ghandehari H. Transepithelial transport and toxicity of PAMAM dendrimers: Implications for oral drug delivery. Adv Drug Deliv Rev. 2012;64(6):571-588.

28. Winnicka K, Bielawski K, Rusak M, Bielawska A. The effect of generation 2 and 3 poly(amidoamine) dendrimers on viability of human breast cancer cells. J Health Sci. 2009;55(2):169-177.

29. Mukherjee SP, Byrne HJ. Polyamidoamine dendrimer nanoparticle cytotoxicity, oxidative stress, caspase activation and inflammatory response: experimental observation and numerical simulation. Nanomedicine. 2013;9(2):202-211.

30. Roberts JC, Bhalgat MK, Zera RT. Preliminary biological evaluation of poly(amidoamine) (PAMAM) starburst dendrimers. J Biomed Mater Res. 1996;30(1):53-65.

31. Heiden TCK, Dengler E, Kao WJ, Heideman W, Peterson RE. Developmental toxicity of low generation PAMAM dendrimers in zebrafish. Toxicol Appl Pharmacol. 2007;225(1):70-79.

32. Malik N, Wiwattanapatapee R, Klopsch R, et al. Dendrimers: relationship between structure and biocompatibility in vitro, and preliminary studies on the biodistribution of I-125-labelled poly(amidoamine) dendrimers in vivo. J Control Release. 2000;65(1-2):133-148. 
33. Chauhan AS, Jain NK, Diwan PV. Pre-clinical and behavioural toxicity profile of PAMAM dendrimers in mice. Proc R Soc A . 2010;466(2117): 1535-1550.

34. Pryor JB, Harper BJ, Harper SL. Comparative toxicological assessment of PAMAM and thiophosphoryl dendrimers using embryonic zebrafish. Int J Nanomedicine. 2014;9:1947-1956

35. Winnicka K, Wroblewska M, Wieczorek P, Sacha PT, Tryniszewska E. Hydrogel of ketoconazole and PAMAM dendrimers: formulation and antifungal activity. Molecules. 2012;17(4):4612-4624.

36. Tang W, Bhushan B. Adhesion, friction and wear characterization of skin and skin cream using atomic force microscope. Colloids Surf B Biointerfaces. 2010;76(1):1-15.

37. Godin B, Touitou E. Transdermal skin delivery: predictions for humans from in vivo, ex vivo and animal models. Adv Drug Deliv Rev. 2007; 59(11):1152-1161.

38. Takeuchi H, Mano Y, Terasaka S, et al. Usefulness of rat skin as a substitute for human skin in the in vitro skin permeation study. Exp Anim. 2011;60(4):373-384.

39. Hall PA, Levison DA, Woods AL, et al. Proliferating cell nuclear antigen (PCNA) immunolocalization in paraffin sections: an index of cell proliferation with evidence of deregulated expression in some neoplasms. J Pathol. 1990;162(4):285-294.
40. Pietrovski EF, Paludo KS, Mendes DA, et al. B1 and B2 kinin receptor participation in hyperproliferative and inflammatory skin processes in mice. J Dermatol Sci. 2011;64(1):23-30.

41. Daidone MG, Silvestrini R. Prognostic and predictive role of proliferation indices in adjuvant therapy of breast cancer. J Natl Cancer Inst Monogr. 2001;(30):27-35.

42. Kawahira K. Immunohistochemical staining of proliferating cell nuclear antigen (PCNA) in malignant and nonmalignant skin diseases. Arch Dermatol Res. 1999;291(7-8):413-418.

43. Laitakari J, Harrison D, Stenbäck F. Automated image analysis of proliferating cells in carcinoma of the larynx. Acta Otolaryngol. 2003;123(6):759-766.

44. Gordón-Núnéz MA, Godoy GP, Soares RC, Souza LB, Freitas RA, Queiroz LM. Inmunohistochemical expression of PCNA, p53 and bcl-2 in pleomorphic adenomas. Int J Morphol. 2008;26(3):567-572.

45. Kömüves LG, Hanley K, Man MQ, Elias PM, Williams ML, Feingold KR. Keratinocyte differentiation in hyperproliferative epidermis: Topical application of PPAR alpha activators restores tissue homeostasis. J Invest Dermatol. 2000;115(3):361-367.

\section{Publish your work in this journal}

Drug Design, Development and Therapy is an international, peerreviewed open-access journal that spans the spectrum of drug design and development through to clinical applications. Clinical outcomes, patient safety, and programs for the development and effective, safe, and sustained use of medicines are a feature of the journal, which has also been accepted for indexing on PubMed Central. The manuscript management system is completely online and includes a very quick and fair peer-review system, which is all easy to use. Visit http://www.dovepress.com/testimonials.php to read real quotes from published authors.

Submit your manuscript here: http://www.dovepress.com/drug-design-development-and-therapy-journal 